\title{
TULVANIITTYTUTKIMUKSIA HELSINGIN YLIOPISTON KOETILALLA INARIN MUDDUSNIEMESSÄ
}

\author{
Onni Pohjakallio ja Kaiho Laurila \\ Kasvipatologian laitos, Helsingin Yliobiston Viikin koetila, Malmi.
}

Saapunut 17. 6. 1955

Helsingin Yliopiston koetilalla Inarin Muddusniemessä pellot ovat karkeata hietamaata, joka varsinkin poutakesinä tarvitsee runsaasti karjanlantaa tuottaakseen edes tyydyttävän sadon. Siten tulvaniityt ovat koetilalle tarpeelliset paitsi pellon parantamista myös rehusadon turvaamista silmällä pitäen (vrt. 8 ja 22). Vastaavasti on epäilemättä asian laita myös monella muulla Perä-Lapin maatilalla, joskin uudisraivausta on pyritty suuntaamaan myös kosteille turvemaille.

Kun Muddusniemen koetilan tulvaniityn tuottoisuus on kuitenkin varsin heikko ja sadon korjuu vaatii suhteellisen suuria kustannuksia, aloitettiin vuonna 1947 tutkimukset, joiden tarkoituksena oli selvittää tulvaniityn satoisuuden parantamismahdollisuuksia. Vaikkakin tulvavesi vuonna 1952 kohosi niin korkealle, että tutkitut menettelytavat osoittautuivat täysin tehottomiksi ja samalla aiheuttivat tutkimustyön keskeyttämisen, kertyi jo suoritetuista töistä runsaasti arvokkaita kokemuksia.

Professorit Viljo Kujala ja Risto Tuomikosk1, jotka v. 1950 kävivät tutustumassa ko. tulvaniittyyn sekä professori MAUno KotiLAINEN ovat hyväntahtoisesti tarkistaneet eräitä kasvilajinmäärityksiä, mistä heille lausumme parhaat kiitoksemme.

\section{Muddusniemen koetilan tulvaniittyalue}

Koetila sijaitsee n. 18 km Inarin kirkolta pohjoiseen, Muddusjärven pohjoisrannalla, siihen pohjoisesta laskevan Kaamasenjoen suussa $\left(69^{\circ} 4^{\prime}\right.$ pohjoista leveyttä ja $27^{\circ} 3^{\prime}$ itäistä pituutta). Tulvaniityt ovat joen molemmilla puolilla $200-300 \mathrm{~m}: \mathrm{n}$ levyisinä lakeuksina (kuva 1), joista n. 50 ha kuuluu Muddusniemen koetilaan. Koko niitty jää yleensä vuosittain kevättulvan alle, lukuunottamatta korkeata, ainoastaan 5-20 metrin levyistä, jokeen jyrkästi viettävää rantaäyrästä, joka useimmiten ulottuu hiukan vedenpinnan yläpuolelle. Pohjamaa on moreenisoraa; sen päällä on 


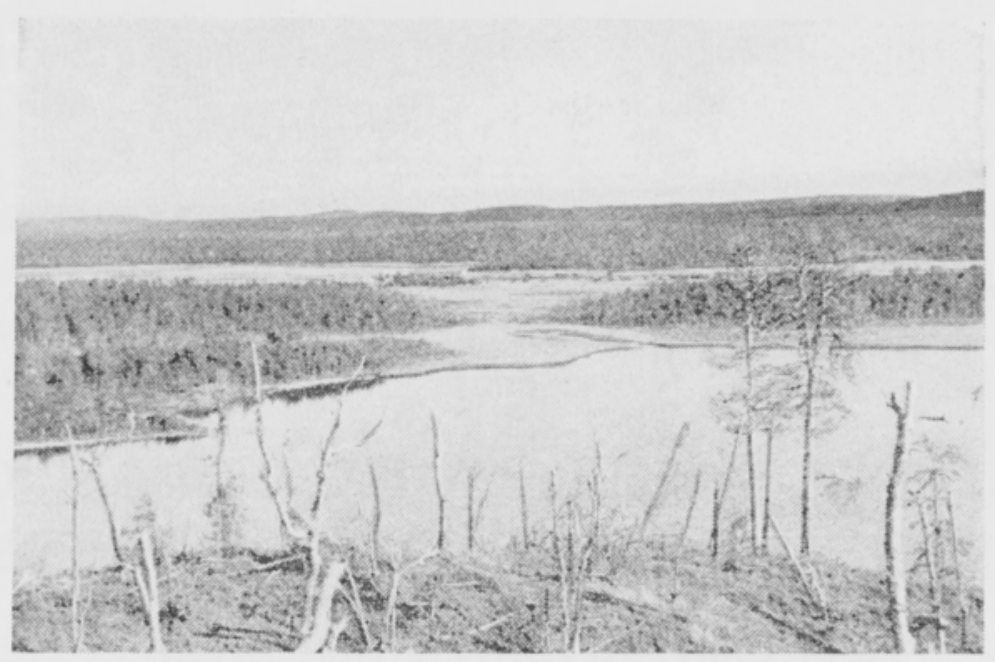

Kuva 1. Muddusjärven takaa näkyy Kaamasenjoen laakso tulvaniittyalueineen.

Abb. 1. Hinter dem Muddusjärvi-See erblickt man das Tal des Flusses Kaamasenjoki und dessen Überschwemmungswiesen.

karkeata hietaa ja hiesua, joihin vesi on tuonut vähän lietettä, mitä on myös sekaantunut saran ja sammalen muodostamaar $10-20 \mathrm{~cm}$ :n paksuiseen turvekerrokseen. Maan reaktio heti turvekerroksen alla oli v. $1948 \mathrm{pH} 4.3-5.0$.

\section{Veden korkeuden vaihtelu tulvaniittyalueella}

Veden korkeuden vaihtelu (kuva 2) oli sääsuhteista riippuvainen (vrt. 3) sekä tulvaniityn tasaisuus huomioonotettuna hyvin tuntuva. V. 1950 olivat tutkitut koealueet koko kesän suurimmaksi osaksi veden pinnan yläpuolella, vuosina 1948 ja 1949 ne olivat keväällä veden peitossa, mutta kesän kuluessa pääasiassa paljastuivat, vuonna 1952 vesi peitti tutkitut alueet kokonaan. Valitettavasti ei kesällä 1952 tehty tarkkoja veden korkeusmittauksia. Irrallisten havaintojen perusteella on kuitenkin pääteltävissä, että veden korkeuden suurin ero vuosina $1947-1952$ oli yli 1 1/2 m.

\section{Tulvaniittyjen kasvillisuus}

Kasvistossa ilmeni samantapaista, joskaan ei varsin selvää vyöhykkeellisyyttä kuin tulvaniityille on todettu olevan ominaista $(1,6,10,12,14,16,19,21)$. H e i n äk a svi v y öh y k e t t ä esiintyi ainoastaan joen penkalla. Se käsitti vain n. $4 \%$ tulvaniityn koko alasta. Lauhan (Deschampsia caespitosa) ohella siinä esiintyi jonkin verran muita heinälajeja ja saroja; sammalpeite oli niukka tai puuttui kokonaan. M a saravyöhykke e 11 ä, joka vuosina 1948-1949 paljastui 5.-15. 7., lauha puuttui lähes kokonaan. Se käsitti $5-10 \%$ tulvaniittyalueesta; sinä oli Carex aquatilisen ja C. chordorrhizan ohella runsaasti Juncus filiformista. Heinistä Calamagrostis lapponica oli leimaa antava. Ruohoista tärkeimmät olivat Comarum palustre, Menyanthes trifoliata ja Caltha palustris. Pientä varvukkoa ja pensaikkoa 


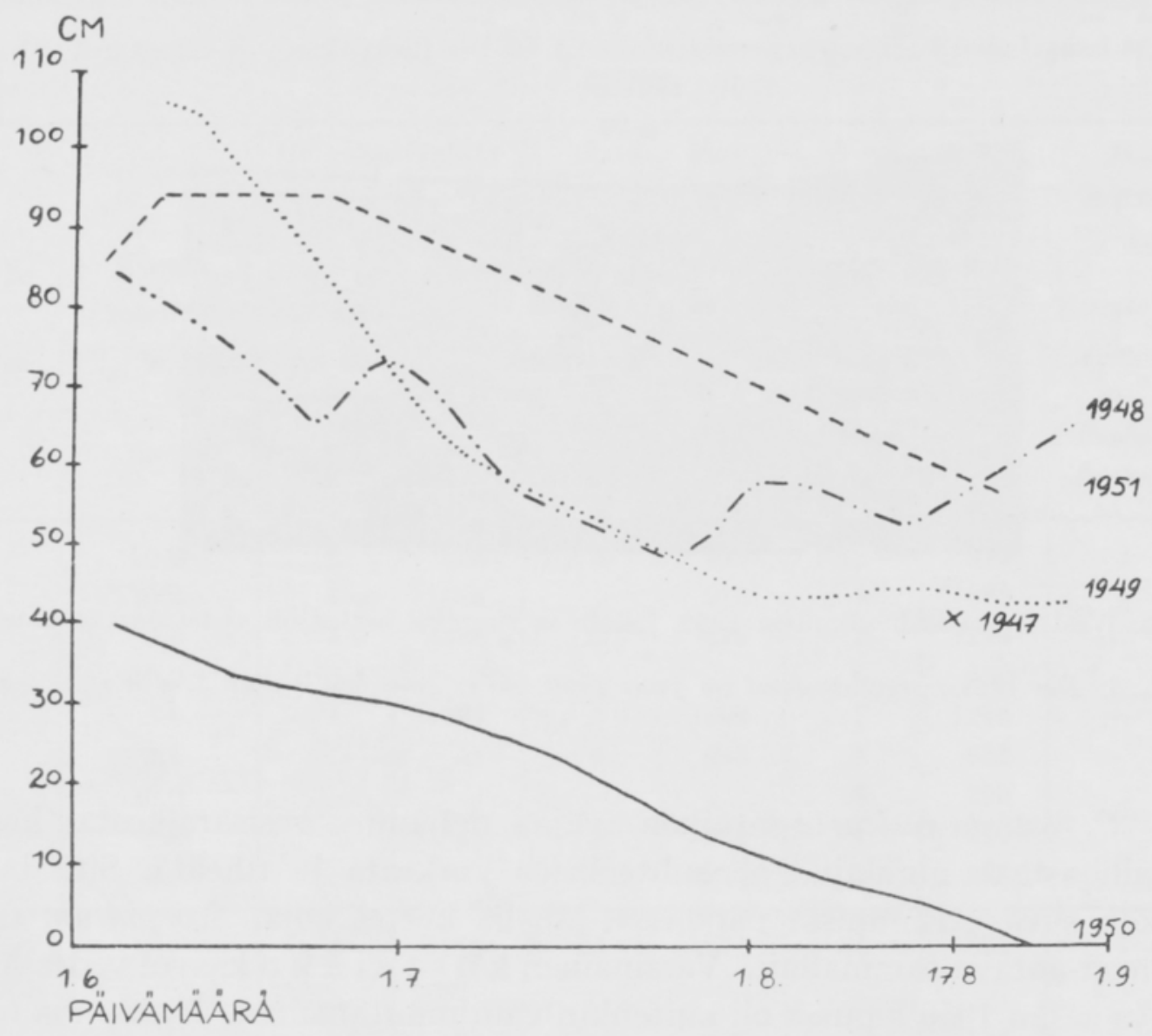

Kuva 2. Kaamasenjoen vedenkorkeuden vaihtelut eksinä 1948-1951.

Abb. 2. Die Wasserstandsschwankungen im Fluss Kaamasenjoki in den Sommern 1948-1951.

(Andromeda, Salix) esiintyi varsin yleisesti. Sarat olivat Carex canescensia ja C. vesicariaa lukuunottamatta, samoin kuin heinäkasvivyöhykkeelläkin, sterilejä. Sen sijaan Juncus filiformis, Rubus arcticus, Pedicularis palustris, P. sceptrum-carolinum ja Menyanthes trifoliata kukkivat. Sammalkerros oli tiivis, pääasiallisesti Polytrichum swartziin (tai ehkä P. jenseniin) muodostama. V e s i s a r o j e n v y öh y k e paljastui vedestä v. 1951 osittain vasta elokuun loppuun mennessä, 1948 pääasiassa heinäkuun ja elokuun puolivälissä. V. 1950 kesän lopulla se oli jokseenkin kokonaan vedettömällä alueella (kuva 3). Tämä alue on huomattavan laaja, n. $2 / 3$ tulvaniityn koko pinta-alasta. Siinä havaittiin toisistaan eroavia Carex aquatilis-, C. chordorrhiza- ja C. rostrata-vesicaria-saraikkoja. Yli puolet vesisaraikosta oli C. aquatilis-saraikkoa, jossa nimilajin lisäksi oli vähävetisimmillä paikoilla C.canescens-tuppaita, hiukan Juncus filiformista sekä joitakin Comarum-, Menyanthes-, Caltha- ja Pedicularis-yksilöitä. Lisäksi oli kortetta, jonka osuus lisääntyi veden syvenemisen mukaisesti. Sammalkerros oli pääasiassa Polytrichum swartziita. Tämän saraikon korkeus ja tiheys oli hyvin vaihtelevaa. - C. chordorrhiza-saraikossa (lähes neljännes vesisaraikosta) oli saman verran C. aquatilista kuin nimilajiakin. Kortetta oli melko runsaasti. Niin saraikko kuin korteikkokin oli harvaa ja matalaa. Sammalkerroksessa oli Polytrichum swartziin lisäksi runsaasti Sphagnum platyphyl- 


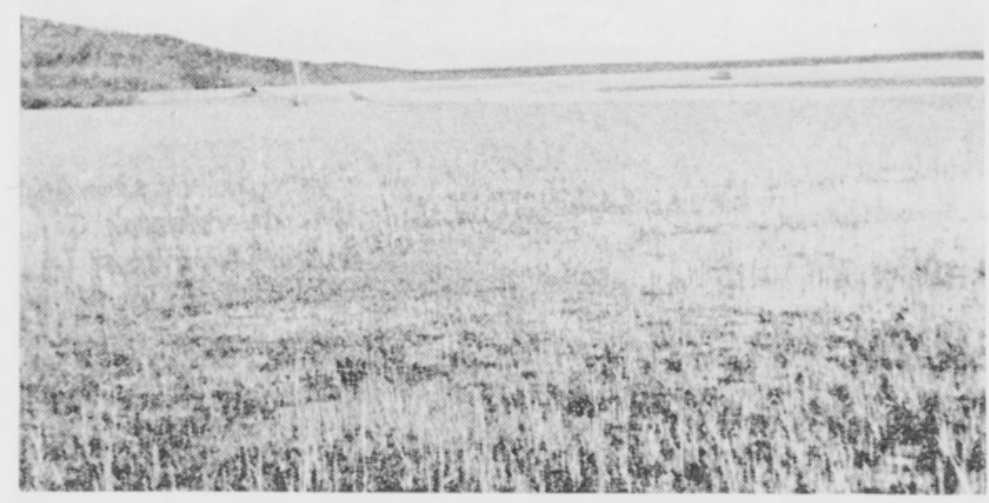

Kuva 3. Vesisaraikkoa kesäkuussa 1950 , jolloin se suureksi osaksi oli vedettömällä alueella.

Abb. 3. Der Wasserseggenbestand im Juni 1950, als er grossénteils über dem Wasser lag.

lumia. - C. rostrata-vesicaria-saraikon (vajaa neljännes vesisaraikosta) kasvusto, melkein ainoastaan nimilajia, oli suhteellisen korkeata ja tiheätä. Sitä tavattiin vesisaraikon syvävetisimmissä paikoissa, lähellä korteikkoja. Scorpidium scorpioides oli leimaa-antava sammallaji. Varsinainen k o r t e i k k o kasvoi vedessä, jonka alin syvyys kesän 1950 lopussa oli kuitenkin vain muutama cm. Equisetum limosum (lähes viidennes tulvaniittyalueesta) muodosti sangen puhtaita kasvustoja. Maan pinnassa (veden alla) oli harvaa Scorpidium scorpioides-sammalikkoa. - Loppuosa tulvaniitystä oli pajukkoa, jota näytti leviävän niityn kuivimmille paikoille.

Yksityiskohtaisia kasvilajinmäärityksiä tehtiin vuosina 1948-1950, yhteensä 70:Itä yhden $\mathrm{m}^{2}: \mathrm{n}$ suuruiselta koealalta, eri puolilta tulvaniittyä. Koealoista oli 18 heinäkasviniityllä, 26 maasaraikossa, 23 vesisaraikossa ja 3 korteikossa. Kuten TERÄSvUORI (18) on osoittanut, eivät näin pienet ja vähälukuiset koealat riitä antamaan tyhjentävää kuvaa tutkitun tulvaniityn kasvilajistosta. Samaan suuntaan vaikuttaa sekin, että monet kasvit esiintyivät steriileinä, jollaisina niiden lajinmääritys tuotti suuria vaikeuksia. Erikoiskokeiden tuoresadoista tehtiin punnittuja botaanisia satoanalyysejä. Tällöin ei kuitenkaan ollut mahdollista punnita kutakin luonnonvaraista kasvilajia erikseen, vaan tyydyttiin karkeaan ryhmitykseen: (luonnon)heinät, sarat, kortteet, ruohot ja varvut. Mitkä kasvilajit on näihin eri ryhmiin sisällytetty, selviää seuraavasta lajiselostuksesta.

H e in äk a s vila j e j a todettiin 14 (joista tosin eräs Calamagrostis-laji, jota hiukan löydettiin vesisaraikon kuivimmilla kohdilla, jäi lajilleen määrittämättä). Näistä oli valtalaji Deschampsia caespitosa; sitä esiintyi pääasiassa heinäkasvivyöhykkeessä ja hiukan maasaraikossa. Pääasiassa samoilla paikoilla esiintyivät myös Anthoxanthum odoratum, Festuca rubra, F. ovina, Monilia coerulea, Poa palustris ja P. pratensis samoin kuin Agrostis canina ja A. stolonifera, jotka rehevimmät kasvustonsa muodostivat kuitenkin maasaraikossa. Samoin kuin edellä mainittu tarkemmin määrittämätön Calamagrostis-laji, myös $C$. lapponica ja $C$. neglecta samoin kuin 
Taulukko 1. Muddusniemen koetilan tulvaniityn sato (15\% kosteutta) kesinä 1948-1951.

Tabelle 1. Die Erträge (15\% Feuchtigkeit) auf der Überschwemmungswiese des Versuchsgutes Muddusniemi in den Sommern 1948-1951.

\begin{tabular}{|c|c|c|c|c|c|c|c|c|c|}
\hline \multirow{2}{*}{$\begin{array}{l}\text { Vuosi } \\
\text { Jahr }\end{array}$} & \multirow{2}{*}{$\begin{array}{c}\text { Koeala } \\
\text { Probefläche } \\
\mathrm{m}^{2}\end{array}$} & \multicolumn{2}{|c|}{$\begin{array}{c}\text { Heinäkasviniitty } \\
\text { Graswiese }\end{array}$} & \multicolumn{2}{|c|}{$\begin{array}{l}\text { Maasaraikko } \\
\text { Landseggen- } \\
\text { bestand }\end{array}$} & \multicolumn{2}{|c|}{$\begin{array}{l}\text { Vesisaraikko } \\
\text { Wasserseggen- } \\
\text { bestand }\end{array}$} & \multicolumn{2}{|c|}{$\begin{array}{l}\text { Korteikko } \\
\text { Schachtelhalm- } \\
\text { bestand }\end{array}$} \\
\hline & & $\begin{array}{c}\text { Koealoja } \\
\text { Anzahl } \\
\text { der } \\
\text { Probe- } \\
\text { flächen }\end{array}$ & $\mathrm{kg} / \mathrm{ha}$ & $\begin{array}{c}\text { Koealoja } \\
\text { Anzahl } \\
\text { der } \\
\text { Probe- } \\
\text { flächen }\end{array}$ & $\mathrm{kg} / \mathrm{ha}$ & $\begin{array}{c}\text { Koealoja } \\
\text { Anzahl } \\
\text { der } \\
\text { Probe- } \\
\text { tlächen }\end{array}$ & $\mathrm{kg} / \mathrm{ha}$ & $\begin{array}{c}\text { Koealoja } \\
\text { Anzahl } \\
\text { der } \\
\text { Probe- } \\
\text { flächen }\end{array}$ & $\mathrm{kg} / \mathrm{ha}$ \\
\hline $\begin{array}{c}1948 \\
1949 \\
\text { " } \\
\text { " } \\
\text { " } \\
\text { " } \\
1951 \\
\text { " }\end{array}$ & $\begin{array}{r}10.0 \\
10.0 \\
5.0 \\
10.0 \\
5.0 \\
2.4 \\
10.0 \\
5.0 \\
2.4\end{array}$ & $\begin{array}{l}2 \\
1 \\
4\end{array}$ & $\begin{array}{r}955 \\
1588 \\
1388\end{array}$ & $\begin{array}{l}4 \\
1 \\
3\end{array}$ & $\begin{array}{r}883 \\
918 \\
879 \\
1209 \\
848 \\
1144 \\
974\end{array}$ & $\begin{array}{r}18 \\
8 \\
2 \\
6 \\
2 \\
8 \\
6 \\
1 \\
3\end{array}$ & $\begin{array}{r}672 \\
888 \\
1129 \\
432 \\
1296 \\
522 \\
299 \\
720 \\
903\end{array}$ & $\begin{array}{l}3 \\
4\end{array}$ & $\begin{array}{l}1173 \\
1162\end{array}$ \\
\hline $\begin{array}{c}\text { Keskim. } \\
\text { Im Mittel } \\
\text { Vaihtelu } \\
\text { Variation }\end{array}$ & & 14 & $\begin{array}{c}1266 \\
\\
494- \\
1722\end{array}$ & 24 & $\begin{array}{c}974 \\
\\
570- \\
1565\end{array}$ & 54 & $\begin{array}{c}138- \\
1496\end{array}$ & 7 & $\begin{array}{c}1167 \\
765- \\
1447\end{array}$ \\
\hline
\end{tabular}

Hierochloe odorata esiintyvät pääasiassa maa- ja vesisaraikon rajalla, mutta jossakin määrin aina heinäkasvivyöhykkeellä asti.

R u o ho is t a (16 lajia) Caltha palustris, Comarum palustre, Crepis sp., Epilobium palustre, Galium palustre, G. uliginosum, Menyanthes trifoliata, Parnassia palustris, Polygonum viviparum, Ranunculus reptans, Stellaria sp., Trientalis europaea, Veronica longifolia ja Viola palustris esiintyivät heinäkasvi-ja saravyöhykkeillä. Cornus suecicaa ja Rubus arcticusta tavattiin vain heinäkasvi- ja maasara-, Pedicularis palustrista ja P. sceptrum-carolinumia vain maasara-vesisara-vyöhykkeillä.

S a r o je n ryhmään (12 lajia) on tässä yhteydessä viety Carex-lajien lisäksi myös eräitä muita kasveja. Juncus filiformista tavattiin molemmilla saravyöhykkeillä, pääasiassa kuitenkin maasaraikossa ja aivan vähän heinäkasvivyöhykkeessäkin. Vesisaravyöhykkeessä oli joitakin Juncus nodulosus- ja J. stygius-yksilöitä. Eriophorum polystachyumia esiintyi kohtalaisen runsaasti vesisara-, hiukan myös maasara- ja heinäkasvivyöhykkeessä. Saraikoissa, pääasiassa kuitenkin maasaraikossa, esiintyi Luzula můtifloraa; vesisaraikossa hiukan myös L. sudeticaa. Viisi saralajia tavattiin paitsi molemmilla saravyöhykkeellä myös heinäkasvivyöhykkeellä. Näistä Carex chordorrhiza, C. aquatilis ja C. canescens olivat maasaraikon, C. rostrata ja $C$. vesicaria vesisaraikon päälajit. Lisäksi $C$. lasiocarpaa esiintyi maaja vesisaraikossa jonkin verran. 
Taulukko 2. Lannoituksen vaikutus tulvaniityn koealueella (sadossa $15 \%$ kosteutta, $\mathrm{kg} / \mathrm{ha}$ ). Tabelle 2. Einfluss der Düngung auf den Probeflä chen der Überschwemmungswiese, kg/ha (15\% Feuchtigkeit).

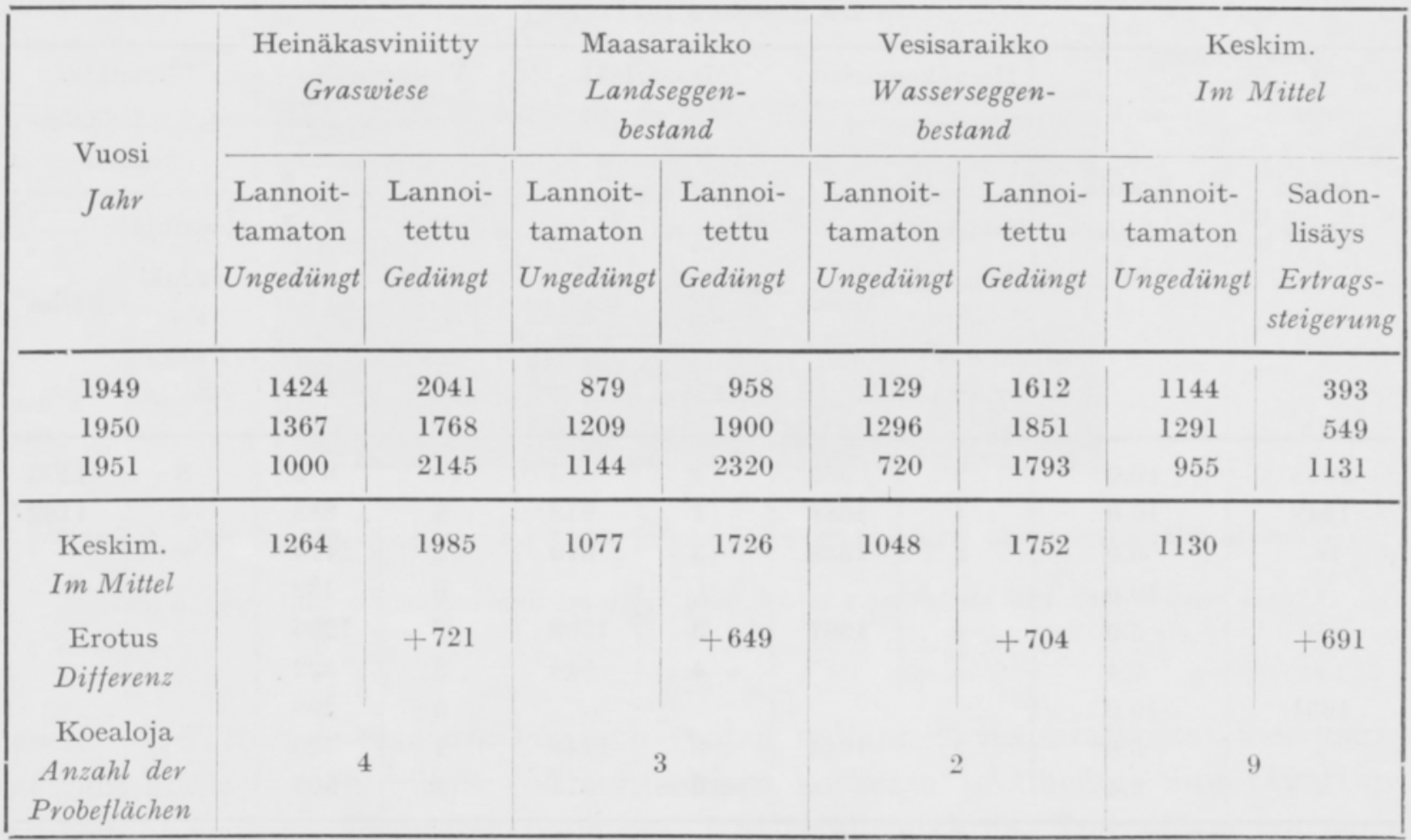

K o r t e i k o t olivat sangen puhtaita Equisetum limosum-kasvustoja; muilla kasvillisuusvyöhykkeillä kortetta oli vähemmän.

V a r p u jen ryhmään on viety seuraavat tulvaniityltä tavatut kasvilajit: Andromeda polifolia, Betula nana, Oxycoccus quadripetalus, joitakin Salix-lajeja, Vaccinium uliginosum, V. myrtillus ja V. vitis-idaea. Salix-lajit esiintyivät pääasiassa heinäkasvi- ja maasaravyöhykkeissä, jonkin verran myös vesisaraikossa. Samoilla alueilla esiintyi maasaraikossa kuitenkin eniten Andromeda polifoliaa. Muiden "varpujen» yksilöluku oli niin pieni, ettei niiden esiintymisestä eri vyöhykkeillä voitu tehdä luotettavia johtopäätöksiä.

Todetut s a m m a 11 a j it olivat Aulacomnium palustre, Bryum ventricosum, Calliergon stramineum, Campylium stellatum, Climacium dendroides, Drepanocladus fluitans coll., Meesea triquetra, Mnium sp., Polythrichum swartzii, Scorpidium scorpioides, Sphagnum cuspidatum, S. russowii, S. platyphyllum, S. recurvum coll., S. subsecundum, S. papillosum, S. squarrosum ja S. warnstorfianum. Lisäksi tavattiin joukko maksasammalia.

\section{Tulvaniityn sato}

Luonnonheinän sato määritettiin eri puolille tulvaniittyä sijoitettujen koealojen perusteella. Sato niitettiin 15.-25. 8. Vesisaraikko, joka käsitti n. 2/3 Muddusniemen koetilan koko tulvaniittyalueesta, on ollut hyvin heikkosatoista (taul. 1), n. puoleksi sellaista, että sadon niitto on tuskin enää taloudellisesti kannattavaa (vrt. 12). 
Taulukko 3. Vesisaraikon lannoituskoe (sadossa $15 \%$ kosteutta, kg/ha) (vrt. taulukko 7). (Erotuksella $114 \mathrm{~kg} / \mathrm{ha} \mathrm{v.} 1949$ ja $475 \mathrm{~kg} / \mathrm{ha} \mathrm{v.} 1950$ on $95 \%$ varmuus).

Tabelle 3. Düngungsversuch im Gürtel der Wasserseggen (Evträge in kg/ha, $15 \%$ Feuchtigkeit) (vgl. Tab. 7). (Die Differenzen von $114 \mathrm{~kg} / \mathrm{ha}$ i.J. 1949 und $475 \mathrm{~kg} / \mathrm{ha}$ i.J. 1950 sind zu $95 \%$ gesichert).

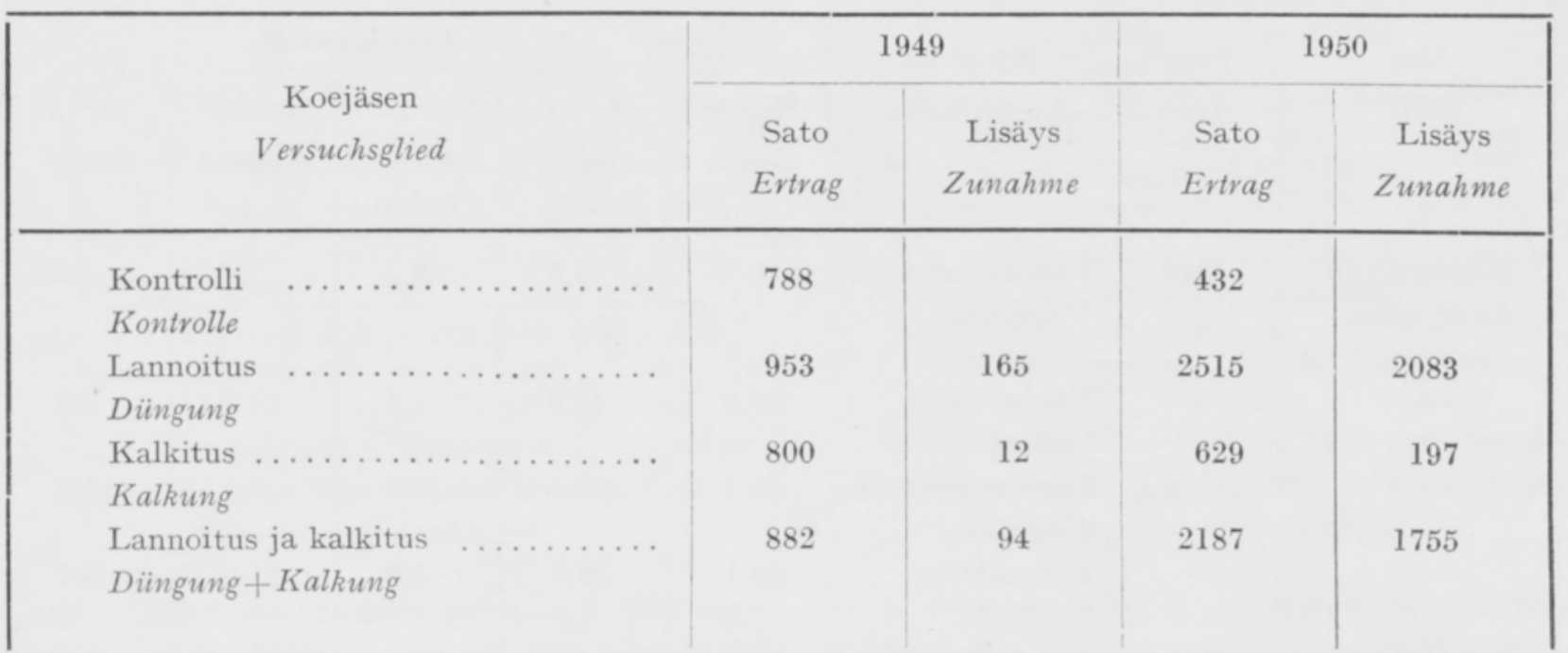

Huomattavia osia tästä saraikosta onkin jätetty niittämättä. Maasaraikkojen sato on ollut hiukan parempi, mutta ainoastaan heinäkasviniityillä ja korteikossa ilmakuivan (15\% kosteutta) sadon määrä oli yli $1000 \mathrm{~kg}$.

\section{Lannoituksen ia kalkituksen vaikutus tulvaniityn satoon}

Lannoituksen vaikutusta tutkittiin tulvaniityn eri puolille sijoitetuilla koealueilla à $10 \mathrm{~m}^{2}$, joista kustakin toinen puoli $\left(5 \mathrm{~m}^{2}\right)$ lannoitettiin (vuosittain ha kohden $800 \mathrm{~kg}$ superfosfaattia, $400 \mathrm{~kg} 40 \%$ kalisuolaa ja $400 \mathrm{~kg}$ kalkkisalpietaria) ja toinen puoli jätettiin lannoittamatta, sekä vesisaraikkoon sijoitetussa erikoiskokeessa (kuva 6), jossa kertausruutuja oli 6, à 10 m²; vuonna 1948 kalkkisalpietarimäärä oli kuitenkin vain $200 \mathrm{~kg} /$ ha; kalkitus oli $3800 \mathrm{~kg}$ sammutettua kalkkia hehtaaria kohden. Kun lannoitteet voitiin levittää vasta keskikesällä, ei niiden vaikutus ollut vielä lannoitusvuonna varmuudella todettavissa. Seuraavina vuosina lannoituksen vaikutus oli sen sijaan selvä ja suureni koekauden jatkuessa (taul. 2 ja 3). Kalkituksella ei tilastollisen virhelaskun (2) valossa ollut varmuudella todettavaa vaikutusta.

Botaaniset satoanalyysit (taul. 4) osoittivat, että maasaraikossa lannoitus lisäsi heinien ja ruohojen sekä vastaavasti vähensi sarojen ja kortteiden osuutta. Vesisaraikossa, jossa suuri kosteus nähtävästi rajoitti heinien ja ruohojen menestymismahdollisuutta, lannoituksen vaikutus sarojen osuuteen sen sijaan melkoisesti vaihteli (taul. 4 ja 6); kortteiden osuus täälläkin pieneni. Kalkituksella ei ollut botaanisen satoanalyysin tulokseen varmuudella todettavaa vaikutusta.

\section{Viljeltyjen nurmikasvilaiien viihtyminen Kaamasenjoen tulvaniittyalueella}

Viljeltyjen nurmikasvien viihtymistä tutkittiin neljässä vuosina $1947-1949$ perustetussa koesarjassa. Koekasvit olivat: Trifolium pratense (Tammisto), T. hy- 
Taulukko 4. Lannoituksen ja kalkituksen vaikutus botaanisen satoanalyysin tulokseen.

Tabelle 4. Einfluss von Düngung und Kalkung auf das Ergebnis der botanischen Evtragsanalyse.

\begin{tabular}{|c|c|c|c|c|c|c|c|}
\hline \multirow{2}{*}{$\begin{array}{l}\text { Alue } \\
\text { Gebiet }\end{array}$} & \multirow{2}{*}{$\begin{array}{l}\text { Vuosi } \\
\text { Jahr }\end{array}$} & \multirow{2}{*}{$\begin{array}{c}\text { Koejäsen } \\
\text { Versuchsglied }\end{array}$} & \multicolumn{5}{|c|}{$\begin{array}{l}\text { Tuorepainosta \% } \\
\% \text { vom Frischgewicht }\end{array}$} \\
\hline & & & $\begin{array}{l}\text { Heinät } \\
\text { Gräser }\end{array}$ & $\begin{array}{l}\text { Sarat } \\
\text { Seggen }\end{array}$ & $\begin{array}{c}\text { Kortteet } \\
\text { Schachtel- } \\
\text { halme }\end{array}$ & $\begin{array}{l}\text { Ruohot } \\
\text { Kräuter }\end{array}$ & $\begin{array}{l}\text { Varvut } \\
\text { Reiser }\end{array}$ \\
\hline $\begin{array}{l}\text { Maasaraikko } \\
\text { Landseggen- } \\
\text { bestand }\end{array}$ & 1949 & $\begin{array}{l}\text { Lannoittamaton } \\
\text { Ungediungt }\end{array}$ & 15.7 & 62.3 & 9.5 & 7.4 & 5.2 \\
\hline$\rightarrow-$ & " & $\begin{array}{l}\text { Lannoitettu } \\
\text { Gedüngt }\end{array}$ & 32.3 & 48.9 & 4.1 & 11.0 & 3.8 \\
\hline$\longrightarrow-$ & 1950 & $\begin{array}{l}\text { Lannoittamaton } \\
\text { Ungedïngt }\end{array}$ & 19.4 & 53.0 & 6.6 & 8.1 & 13.0 \\
\hline$\longrightarrow$ & $"$ & $\begin{array}{l}\text { Lannoitettu } \\
\text { Gedüngt }\end{array}$ & 58.1 & 39.2 & 1.5 & 21.6 & 8.7 \\
\hline $\begin{array}{l}\text { Vesisaraikko } \\
\text { Wasserseggen- } \\
\text { bestand }\end{array}$ & 1949 & $\begin{array}{l}\text { Lannoittamaton } \\
\text { Ungedïngt }\end{array}$ & 0.0 & 54.2 & 35.6 & 9.3 & 0.9 \\
\hline$\rightarrow-$ & $"$ & $\begin{array}{l}\text { Lannoitettu } \\
\text { Gedïngt }\end{array}$ & 0.0 & 62.3 & 33.6 & 2.0 & 2.3 \\
\hline$\longrightarrow-$ & 1950 & $\begin{array}{l}\text { Lannoittamaton } \\
\text { Ungediungt }\end{array}$ & 0.0 & 50.9 & 44.2 & 1.1 & 3.8 \\
\hline$\longrightarrow-$ & $"$ & $\begin{array}{l}\text { Lannoitettu } \\
\text { Gedüngt }\end{array}$ & 1.9 & 79.0 & 17.6 & 0.0 & 1.5 \\
\hline$\rightarrow$ & " & $\begin{array}{l}\text { Kalkittu } \\
\text { Gekalkt }\end{array}$ & 0.0 & 53.4 & 45.2 & 0.7 & 0.7 \\
\hline$\rightarrow-$ & , & $\begin{array}{l}\text { Lann. ja kalk. } \\
\text { Dïngung }+ \\
\text { Kalkung }\end{array}$ & 1.6 & 79.0 & 25.5 & 0.7 & 1.2 \\
\hline
\end{tabular}

bridum (Tammisto), T. repens (Tammisto), Lotus corniculatus (Jokioinen), Phleum pratense (Tarmo), Festuca pratensis (Paavo), Dactylis glomerata (Tammisto), Alopecurus pratensis (suomal. kauppasiemen), Poa pratensis (Adila), P. serotina (Hammenhög), P.trivialis (ruotsal. kauppasiemen), Poa alpigena (pohjois-Suomi), Agrostis stolonifera (Hiipinä), Bromus inermis (Jokioinen) ja Glyceria fluitans (Helsinki). Nurmipalkokasvien siemen ympättiin nystyräbakteereilla. Lannoitus ja kalkitus olivat pääasiallisesti samanlaiset kuin edellä selostetuissa luonnonvaraisilla kasveilla suoritetuissa kokeissa, paitsi vuonna 1947 perustetussa kokeessa, jossa peruslannoitus annettiin makkilantana (n. 30 t/ha). Muokkaus suoritettiin kuokalla, paitsi v. 1949 perustetussa kokeessa Vikkelä-äkeellä.

Koesarjoista oli 3 ns. ka ista k o ke it a, joissa koealat pitkinä, kapeina kaistoina ulottuivat kokeen perustamisvuoden alimmasta vedenkorkeudesta koealueen korkeimmalle kohdalle; siten oli mahdollista tutkia koekasvien menestymistä erilaisissa tulvavesiolosuhteissa. Koekaistojen etäisyys toisistaan oli $1.2-1.5 \mathrm{~m}$; niiden pituus ja leveys vaihteli eri kokeissa; kaistojen pituus oli riippuvainen maan 


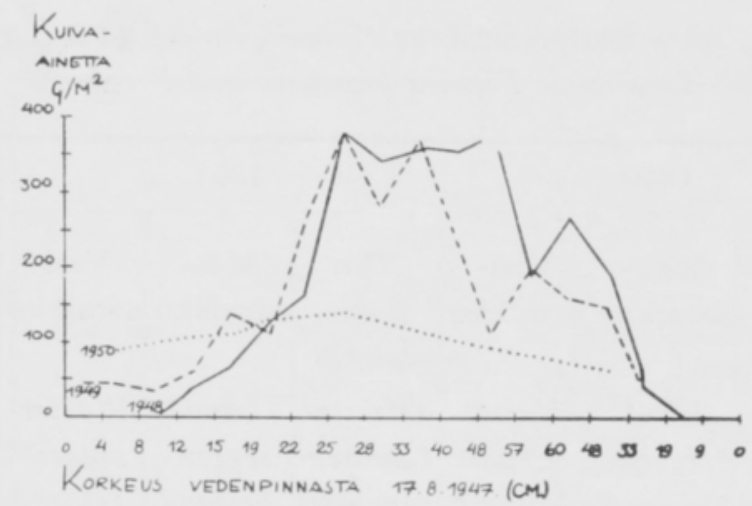

Kuva 4. Satotulokset v. 1947 perustetussa kaistakokeessa, joka ulottui heinäkasvivyöhykkeestả vesisaraikkoon.

Abb. 4. Die Ertragsresultate in dem i.J. 1947 angelegten Streifenversuch, der sich vom Grasgürtel bis zum Wasserseggengürtel erstreckte.

viettävyyssuhteista; veden pinnan ja korkeimman maastokohdan välinen korkeusero koetta perustettaessa oli eri kokeissa $50-60 \mathrm{~cm}$. Näitä kokeita perustettiin v. 1947 (8 kaistaa, leveys $40 \mathrm{~cm}$, pituus $6-18 \mathrm{~m})$, v. 1948 (12 kaistaa, leveys $120 \mathrm{~cm}$, pituus $5 \mathrm{~m}$ ) ja v. 1949 (22 kaistaa, leveys $120 \mathrm{~cm}$, pituus $50 \mathrm{~m}$ ). - Neljäs koesarja oli tavanomainen kenttäkoe (koeruudut $6 \times 10 \mathrm{~m}^{2}$, kuva 6 ).

Siemennyksellä oli sadon määrään oleellista vaikutusta ainoastaan lannoitetuilla koealoilla (kuva 8, taul. 5 ja 7). Kalkituksella, varsinkin lannoituksen ohella, oli pikemminkin haitallinen kuin satoa lisäävä vaikutus (taul. 7). Kylvetyt kasvit jäivät lannoittamattomilla koealoilla kitukasvuisiksi ja steriileiksi; siten muokkaus, joka tuhosi luonnonvaraiset kasvit, pienensi sadon määrää. V.1948 perustetussa kaistakokeessa kylvetyt nurmikasvit (45 kg/ha), josta $45 \%$ timoteita, $45 \%$ nurmipuntarpäätä ja loput muita nurmiheiniä) menestyivät huonosti myös muokatuilla ja lannoitetuilla koealoilla (kuva 6). Yleensä kuitenkin yhdistetty muokkaus ja lannoitus aiheutti seuraavana vuonna kylvettyjen nurmikasvien huomattavan rehevöitymisen. Ilmakuiva sato kohosi 3000-4000 kiloon hehtaaria kohden (kuva 4) eli lannoittamattoman luonnonheinän satoon verrattuna 4-9 kertaiseksi, kuitenkin vain 1.2 - 1.4 kertaa suuremmaksi kuin lannoitetun luonnonheinän sato. Yleensä siemennyksen vaikutus oli lyhytaikainen; sen osuus sadon määrään ilmeni oleellisena vain parin vuoden ajan. Sitä paitsi kylvetyt heinät viihtyivät vain tulvaniityn heinäkasvi- ja maasara-alueilla eli n. kymmenesosalla tutkitun niityn koko pinta-alasta. V. 1952, jolloin vesi peitti suurimman osan tulvaniitystä koko kesän ajan (kuva 7), kylvetyt nurmikasvit kauttaaltaan tuhoutuivat. 
Taulukko 5. V. 1949 perustetun kaistakokeen kuiva-ainesadot (kg/ha). (Siemenseos $40 \mathrm{~kg} / \mathrm{ha}$ pääasiassa timoteita ja nurmipuntarpäätä; lisäksi vähän nurminataa ja puna-nataa).

Tabelle 5. Trockensubstanzerträge (kg/ha) des i.J. 1949 angelegten Streifenversuchs. (Samengemisch $40 \mathrm{~kg} / \mathrm{ha}$, hauptsächlich Phleum pratense und Alopecurus pratensis; dazu etwas Festuca pratensis und F.rubra).

\begin{tabular}{|c|c|c|c|c|c|c|}
\hline \multirow[b]{2}{*}{$\begin{array}{c}\text { Koejäsen } \\
\text { Versuchsglied }\end{array}$} & \multicolumn{3}{|c|}{1950} & \multicolumn{3}{|c|}{1951} \\
\hline & $\begin{array}{c}\text { Ylin } \\
\text { maa- } \\
\text { saraikko } \\
\text { Oberster } \\
\text { Landseg- } \\
\text { gengürtel }\end{array}$ & $\begin{array}{c}\text { Maa- } \\
\text { saraikko } \\
\text { Land- } \\
\text { seggen- } \\
\text { bestand }\end{array}$ & $\begin{array}{c}\text { Vesi- } \\
\text { saraikko } \\
\text { Wasser- } \\
\text { seggen- } \\
\text { bestand }\end{array}$ & $\begin{array}{c}\text { Ylin } \\
\text { maa- } \\
\text { saraikko } \\
\text { Oberster } \\
\text { Landseg- } \\
\text { gengürtel }\end{array}$ & $\begin{array}{c}\text { Maa- } \\
\text { saraikko } \\
\text { Land- } \\
\text { seggen- } \\
\text { bestand }\end{array}$ & $\begin{array}{l}\text { Vesi- } \\
\text { saraikko } \\
\text { Wasser- } \\
\text { seggen- } \\
\text { bestand }\end{array}$ \\
\hline $\begin{array}{l}\text { Lannoittamaton luonnonheinä } \ldots \ldots \ldots \ldots \\
\text { Naturgras, ungedüngt }\end{array}$ & 826 & 311 & 669 & 856 & 799 & 767 \\
\hline $\begin{array}{l}\text { Lannoitettu luonnonheinä } \ldots \ldots \ldots \ldots \ldots \ldots \\
\text { Naturgras, gedüngt }\end{array}$ & 1813 & 716 & 774 & 1726 & 1780 & 1412 \\
\hline $\begin{array}{l}\text { Timotei ( } 30 \mathrm{~kg} / \mathrm{ha}, \mathrm{kylv} \text {. luonnonh. sek.) .... } \\
\text { Phleum pratense, } 30 \mathrm{~kg} / \mathrm{ha} \text { in Naturgras eingesät }\end{array}$ & 546 & 511 & 594 & 563 & 1161 & 684 \\
\hline$\longrightarrow-\quad \begin{array}{l}\text { +lannoitettu } \ldots \ldots \ldots \\
+ \text { gediungt }\end{array}$ & 1979 & 1260 & 799 & 1841 & 1487 & 1307 \\
\hline $\begin{array}{l}+ \text { muokattu ja lannoitettu } \\
+ \text { + bearbeitet und gediungt }\end{array}$ & 2579 & 987 & 750 & 1458 & 1098 & 910 \\
\hline $\begin{array}{l}\text { Nurmipuntarpää (45 kg/ha, kylv. luonnonh. } \\
\text { sek.) } \\
\text { Alopecurus pratensis, } 45 \mathrm{~kg} / \mathrm{ha} \text { in Naturgras } \\
\text { eingesät }\end{array}$ & 962 & 428 & 610 & 815 & 704 & 363 \\
\hline $\begin{aligned} \rightarrow- & + \text { lannoitettu } \ldots \ldots \ldots \\
& + \text { gediingt }\end{aligned}$ & 2528 & 1137 & 1774 & 2160 & 1751 & 1386 \\
\hline $\begin{array}{l}+ \text { muokattu ja lannoitettu } \\
+ \text { bearbeitet und gediungt }\end{array}$ & 2532 & 666 & 730 & 2034 & 1527 & 1187 \\
\hline $\begin{array}{l}\text { Siemenseos ( } 30 \mathrm{~kg} / \mathrm{ha} \text {, kylv. luonnonh. sek.) } \\
\text { Samengemisch, } 30 \mathrm{~kg} / \mathrm{ha} \text { in Naturgras eingesät }\end{array}$ & 548 & 395 & 487 & 720 & 780 & 668 \\
\hline$\longrightarrow$ - $\quad \begin{array}{l}\text { +lannoitettu } \ldots \ldots \ldots \\
\\
+ \text { gedüngt }\end{array}$ & 2509 & 1159 & 957 & 2173 & 1853 & 1302 \\
\hline $\begin{array}{l}\text { + muokattu ja lannoitettu } \\
\text { + bearbeitet und gedïngt }\end{array}$ & 1054 & 687 & 534 & 1741 & 1159 & 1028 \\
\hline
\end{tabular}

Siemennyksiin käytettiin pääasiassa timoteita ja nurmipuntarpäätä; muita nurmikasvilajeja kylvettiin vähemmän, korkeintaan $12.4 \%$ koko siemenmäärästä, tavallisesti vain $1-3 \%$, joten niillä sadon määrään oli vain toisarvoinen vaikutus. Timotei ja nurmipuntarpää osoittautuivat keskenään lähes samanarvoisiksi, kuitenkin siten, että timotein sato aleni vuodesta toiseen nopeammin; maaston korkeuserojen vaikutus ilmeni kummassakin lajissa sangen yhtäläisenä, joskin eräissä kokeissa nurmipuntarpääkasvusto ulottui lähemmäksi vesirajaa. Muista kylvetyistä nurmikasvilajeista Poa-lajit ( $P$. trivialis, $P$. pratensis ja $P$. serotina) muodostivat pysyvimmät kasvustot. Festuca pratensis ja Agrostis stolonifera katosivat nurmesta hyvin nopeasti. Lajeja, joista tavattiin vain muutamia yksilöitä olivat: Poa alpigena, 
Taulukko 6. Botaanisen satoanalyysin tulokset v. 1949 perustetun kaistakokeen sadoista v. 1950 (vrt. taulukko 5).

Tabelle 6. Ergebnisse der botanischen Ertragsanalyse im Streifenversuch der Tabelle 5 i.J. 1950.

\begin{tabular}{|c|c|c|c|c|}
\hline \multirow{3}{*}{$\begin{array}{c}\text { Kasvi } \\
\text { Pflanze }\end{array}$} & \multirow{3}{*}{$\begin{array}{l}\text { Koe- } \\
\text { kaistoja } \\
\text { Versuchs- } \\
\text { streifen }\end{array}$} & \multirow{2}{*}{\multicolumn{3}{|c|}{$\begin{array}{c}\text { Tuorepainosta \% } \\
\% \text { vom Frischgewicht } \\
\text { Korkeusvyöhykkeet } \\
\text { Höhengürtel }\end{array}$}} \\
\hline & & & & \\
\hline & & $\begin{array}{c}\text { Ylin } \\
\text { maasaraikko } \\
\text { Oberster } \\
\text { Landseggen- } \\
\text { gürtel }\end{array}$ & $\begin{array}{l}\text { Maasaraikko } \\
\text { Landseggen- } \\
\text { bestand }\end{array}$ & $\begin{array}{l}\text { Vesisaraikko } \\
\text { Wasserseggen- } \\
\text { bestand }\end{array}$ \\
\hline $\begin{array}{l}\text { Lannoittamattomat koekaistat (keskim.) } \\
\text { Ungedüngte Versuchsstreifen (durchschn.) }\end{array}$ & & & & \\
\hline $\begin{array}{l}\text { Kylvetyt heinät } \quad \ldots \ldots \ldots \ldots \ldots \ldots \ldots \ldots \\
\text { Gesäte Gräser }\end{array}$ & 3 & 0.0 & 0.0 & 0.0 \\
\hline $\begin{array}{l}\text { Luonnonheinät } \ldots \ldots \ldots \ldots \ldots \ldots \ldots \ldots \ldots \ldots \ldots \\
\text { Naturgräser }\end{array}$ & 3 & 9.3 & 0.1 & 0.0 \\
\hline $\begin{array}{l}\text { Ruohot } \\
\text { Kräuter }\end{array}$ & 3 & 21.5 & 1.6 & 0.7 \\
\hline $\begin{array}{l}\text { Sarat } \\
\text { Seggen }\end{array}$ & 3 & 50.4 & 81.3 & 85.7 \\
\hline $\begin{array}{l}\text { Kortteet } \ldots \ldots \ldots \ldots \ldots \ldots \ldots \ldots \ldots \\
\text { Schachtelhalme }\end{array}$ & 3 & 13.7 & 17.0 & 13.0 \\
\hline $\begin{array}{l}\text { Varvut } \\
\text { Reiser } \\
\text { Lannoitetut koekaistat (keskim.) } \\
\text { Gedüngte Versuchsstreifen (durchschn.) }\end{array}$ & 3 & 5.1 & 0.0 & 0.6 \\
\hline Phleum pratense $\ldots \ldots \ldots \ldots \ldots \ldots$ & 4 & 46.5 & 57.5 & 19.6 \\
\hline Alopecurus pratensis $\quad \ldots \ldots \ldots \ldots \ldots$ & 4 & 16.4 & 9.0 & 17.7 \\
\hline Festuca pratensis $\ldots \ldots \ldots \ldots \ldots \ldots$ & 2 & 0.0 & 0.0 & 0.0 \\
\hline Festuca rubra $\quad \ldots \ldots \ldots \ldots \ldots \ldots \ldots$ & 2 & 0.2 & 0.3 & 0.0 \\
\hline $\begin{array}{l}\text { Luonnonheinät } \ldots \ldots \ldots \ldots \ldots \ldots \ldots \ldots \ldots \ldots \ldots \\
\text { Naturgräser }\end{array}$ & 8 & 25.2 & 14.0 & 3.4 \\
\hline $\begin{array}{l}\text { Ruohot } \quad \cdots \cdots \cdots \cdots \cdots \cdots \cdots \cdots \cdots \cdots \cdots \cdots \cdots \\
\text { Kräuter }\end{array}$ & 8 & 18.2 & 1.5 & 0.4 \\
\hline $\begin{array}{l}\text { Sarat } \\
\text { Seggen }\end{array}$ & 8 & 28.4 & 55.2 & 74.6 \\
\hline $\begin{array}{l}\text { Kortteet ........................ } \\
\text { Schachtelhalme }\end{array}$ & 8 & 6.4 & 10.0 & 10.5 \\
\hline $\begin{array}{l}\text { Varvut } \\
\text { Reiser }\end{array}$ & 8 & 2.6 & 0.1 & 1.9 \\
\hline
\end{tabular}

Dactylis glomerata, Festuca rubra, Bromus inermis, Trifolium pratense ja Trifolium hybridum. Trifolium repensiä ja Lotus corniculatusta ei joutunut ainoaankaan satoanalyysiä varten otettuun näytteeseen eikä niitä kylvöä seuraavana eikä myöhempinä vuosina ollut myöskään silmävaraisesti havaittavissa. 
Taulukko 7. V. 1948 perustetun koekentän kuiva-ainesato kesällä 1950 (vrt. taulukko 3).

Tabelle 7. Trockensubstanzerträge (kg/ha) auf dem i.J. 1948 angelegten Versuchsfeld im Sommer 1950 (vgl. Tab. 3).

\begin{tabular}{|c|c|c|c|c|c|}
\hline \multirow[b]{2}{*}{$\begin{array}{l}\text { Siemennys } \\
\text { Besamung }\end{array}$} & \multirow[b]{2}{*}{$\begin{array}{l}\text { Muokkaus } \\
\text { Bearbei- } \\
\text { tung }\end{array}$} & \multirow[b]{2}{*}{$\begin{array}{l}\text { Kalkitus } \\
\text { Kalkung }\end{array}$} & \multirow[b]{2}{*}{$\begin{array}{l}\text { Lannoitus } \\
\text { Düngung }\end{array}$} & \multicolumn{2}{|c|}{$\mathrm{kg} / \mathrm{ha}$} \\
\hline & & & & $\begin{array}{l}\text { Sato } \\
\text { Ertrag }\end{array}$ & $\begin{array}{c}\text { Sadonlisäys }(+) \\
\text {-vähennys }(-) \\
\text { Evtragszu- }(+) \\
\text { bzw. } \\
\text {-abnahme }(-)\end{array}$ \\
\hline 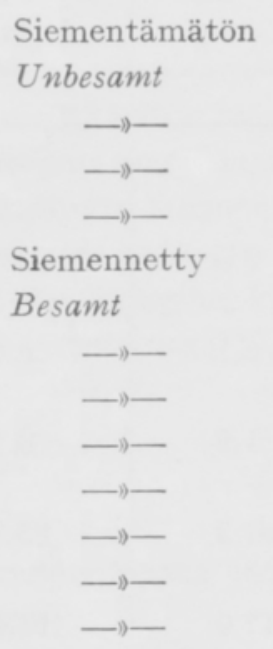 & $\begin{array}{l}+ \\
+ \\
+ \\
+\end{array}$ & $\begin{array}{l}+ \\
+\end{array}$ & $\begin{array}{l}+ \\
+ \\
+ \\
+\end{array}$ & $\begin{array}{r}367 \\
2138 \\
535 \\
1859 \\
432 \\
\\
\\
2408 \\
474 \\
2220 \\
173 \\
2621 \\
139 \\
1855\end{array}$ & $\begin{array}{r}+1771 \\
+168 \\
+1492 \\
+65 \\
+2041 \\
+107 \\
+1853 \\
-194 \\
+2254 \\
-128 \\
+1488\end{array}$ \\
\hline
\end{tabular}

Tuhosieniä esiintyi kylvetyissä nurmiheinissä vain niukasti. Kuitenkin keväällä 1949 tavattiin Typhula-sientä v. 1947 kylvetyn kaistakokeen lähes korkeimmalla kohdalla (kuva 4, 48-50 cm) n. metrin pituisella alueella pahoin tuhoutuneessa timoteikasvustossa erittäin runsaasti. Sienen sklerootiot olivat veden peittämissä kohdissa säilyneet puhtaan valkeina kesäkuun puoliväliin asti. Keväällä 1951, jolloin kylvönurmi tässä kokeessa oli jo lähes kokonaan tuhoutunut, löydettiin timoteista hiukan pohjolan pahkahometta (Sclerotinia borealis). Sen osuus tuhoon oli tuskin kuitenkaan varsin suuri. Tärkeämpi merkitys kylvettyjen nurmiheinien tuhoutumisessa näytti täällä samoin kuin muillakin koealueilla olleen ilmaston ankaruuden ja tulvaveden ohella eräillä sammallajeilla.

Niillä alueilla, joilla kylvetyt nurmiheinät parhaiten menestyivät, erityisesti maasaravyöhykkeellä, oli pääsammallajina Polytrichum swartzii. Mielenkiintoista oli todeta, että tämän sammalen ja timotein viihtymisrajat maaston laskusuunnassa sattuivat hyvin tarkasti samalle korkeudelle veden pinnan tasosta. Lannoitus samoin kuin kalkitus tuhosi $P$. swartziin; lannoitetuilla koeruuduilla sen tilalle ilmestyi kuitenkin toisia sammallajeja (Aulacomnium palustrea, Mniumia ja varsinkin Bryum ventricosumia). Nämä muodostivat sangen nopeasti tiiviin sammalpeitteen maan pinnalle ja siten ilmeisesti tyrehdyttivät nurmikasvilajien kasvua.

V. 1947 kylvetyssä kokeessa Glyceria fluitans muodosti vuosina 1948-1949 puhtaan kasvuston veden peittämille kaistakokeen osille. V. 1950, jolloin veden pinta 


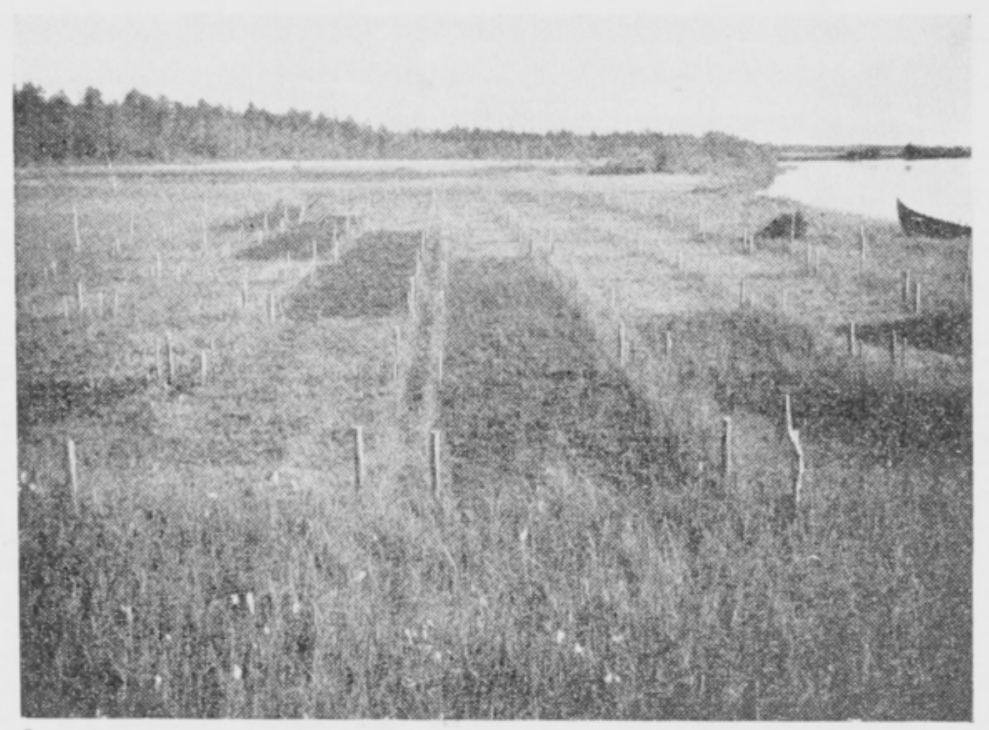

Kuva 6. V. 1948 vesisaraikkoon perustettu tulvaniityn koekenttä sadon korjuun jälkeen elokuun Iopulla 1949 (tummina näkyvät koeruudut ovat muokattuja ja siemennettyjä, mutta lannoittamattomia, vrt. taul. 7).

Abb. 6. Das i. J. 1948 im Wasserseggenbestand angelegte Versuchsfeld nach der Ernte Ende August 1949. Die dunkel hervortretenden Versuchsparzellen sind bearbeitet und besamt, aber ungedïngt (vgl. Tab. 7 ).

oli erityisen alhaalla (kuva 2), luonnonvaraiset kasvit valtasivat sen kasvualaa siinä määrin, että G.fluitansin paino-osuus kasvustosta otetussa näytteessä oli vain $17.3 \%$. Sen jälkeen se on edelleen väistynyt muun kasvillisuuden tieltä, mutta vielä v. 1954 löytyi muutamia G. fluitans-yksilöitä. Joka tapauksessa se osoittautui Kaamasenjoen tulvaniityn karuissa olosuhteissa niukkasatoiseksi ja paikalliseen luonnonvaraiseen kasvillisuuteen verrattuna vain heikosti kilpailukykyiseksi.

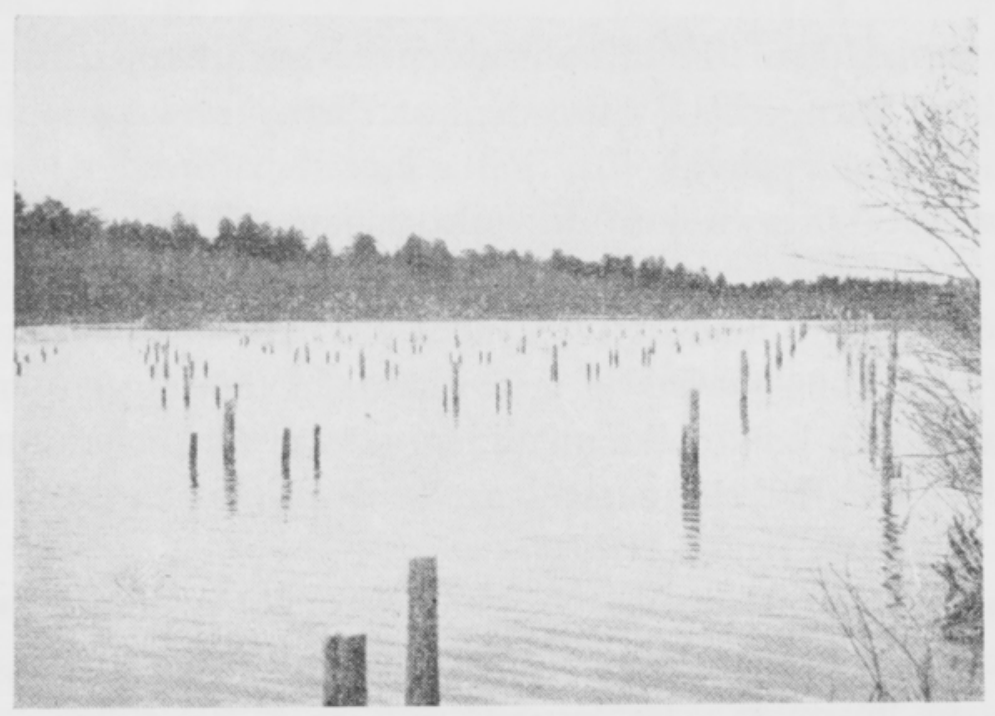

Kuva 7. V. 1948 perustettu tulvaniityn koekenttä veden peitossa kesäkuun alussa v. 1952. Abb. 7. Das i.J. 1948 im Wasserseggenbestand angelegte Versuchsfeld unter Wasser Anfang Juni 1952 


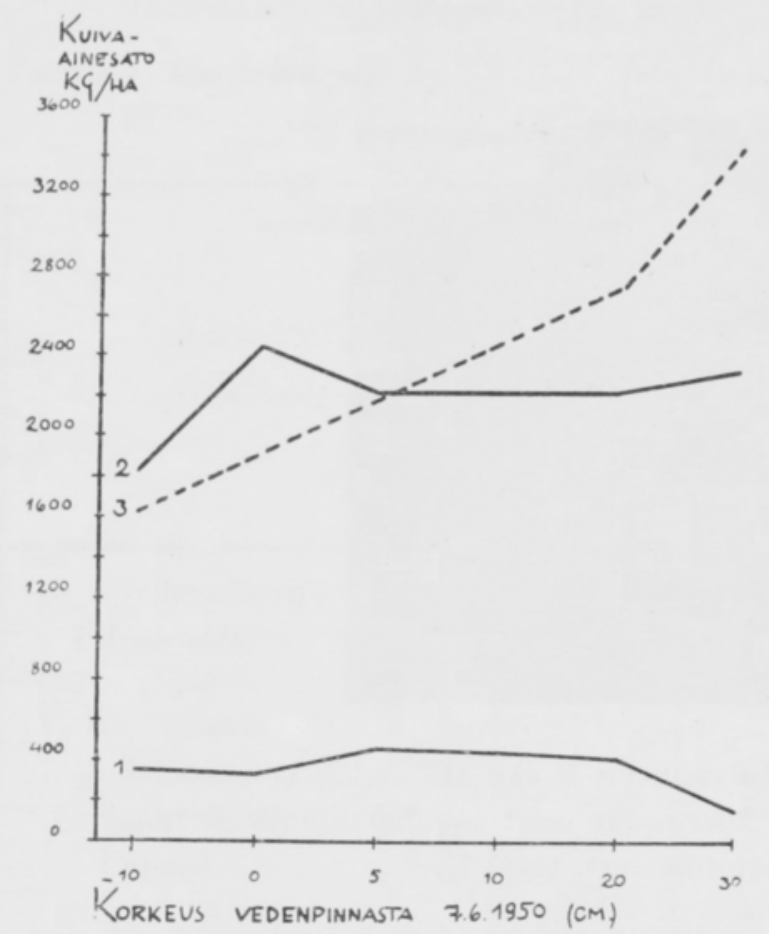

Kuva 8. Korkeussuhteiden vaikutus kuiva-ainesadon määrään v. 1948 perustetussa lannoituskokeessa,

$1=$ lannoittamaton luonnonheinä, $2=$ lannoitettu luonnonheinä, 3 = muokattu, lannoitettu ja siemennetty.

Abb. 8. Einfluss der Höhenverhältnisse auf die Grösse des Trockensubstanzertrags in dem i.J. 1948 angelegten Düngungsversuch.

$1=$ Naturgras, ungedüngt, $2=$ Naturgras, gedünst, 3 = bearbeitet, gedüngt und besamt.

\section{Tutkimusten tulosten tarkastelua}

Tutkitusta tulvaniittyalueesta oli n. 2/3 vesisaraikkoa, 1/5 korteikkoa, vajaa 1/10 maasaraikkoa ja n. 1/25 heinäkasviniittyä. Heinäkasviniittyjen valtakasvi oli Deschampsia caespitosa: KaIteran (7) mukaan se ei menesty alueilla, joilla tulvavesi viipyy yli $11 / 2 \mathrm{kk}: \mathrm{n}$ ajan. Heinäkasviniitty muuttui maan laskusuunnassa vähitellen ensin maa-, sitten vesisaraikoksi ja lopulta kortteikoksi (vrt. 10, 14, 21).

Suurimmat keskimääräiset sadot (ilmakuivat eli $15 \%$ kosteutta) saatiin heinäkasviniityiltä (1266 kg/ha) ja korteikosta $(1167 \mathrm{~kg} / \mathrm{ha})$; maasaraikkojen keskisato oli $974 \mathrm{~kg} / \mathrm{ha}$ ja vesisaraikkojen ainoastaan $667 \mathrm{~kg} / \mathrm{ha}$. Sadon määrän vaihtelu oli suuri, $138-1722 \mathrm{~kg} / \mathrm{ha}$ (taul. 1). Kaamasjoen vesisaraikkojen sadot olivat samaa suuruusluokkaa kuin SAukko (12) on todennut Pirttijärven ja Kiimasjärven tulvaniittyjen ns. tuhoutumisvyöhykkeillä, joilla kasvilajisto veden korkeuden muutoksista johtuen vuodesta toiseen joutuu vaihtumaan. Kaikkiaankin Kaamasenjoen tulvaniityt kuuluvat TERÄSvUOREN (20) jyvitysluokittelun mukaisesti vain hyvin pieneksi osaksi viidenteen $(2000 \mathrm{~kg} / \mathrm{ha})$, pääasiallisesti sensijaan kahteen huonoimpaan eli kuudenteen $(1000 \mathrm{~kg} / \mathrm{ha})$ ja seitsemänteen $(500 \mathrm{~kg} / \mathrm{ha})$ niittyjen jyvitysluokkaan. Parhaimmilla kohdillakaan niiden sato ei ole kohonnut läheskään niin suureksi $(4000-6000 \mathrm{~kg} / \mathrm{ha})$ kuin saadaan tuottoisimmilla tulvaniityillä (vrt. 4, $12,20)$.

Kaamasenjoen tulvaniittyjen sato oli kalkituksella tuskin ollenkaan kohotettavissa, mutta lannoituksen vaikutus oli hyvin tuntuva (taul. 2, 3, 5, 7; kuvat 4, 5, 8) ja ainakin kolmena ensimmäisenä vuonna sen vaikutus vuosi vuodelta suureni. Lannoitus aiheutti niityn kasvilajikoostumuksessa huomattavia muutoksia (taul. $4,6,8)$; kortteiden osuus sadossa selvästi pieneni, heinäkasvien osuus suureni ja saro- 
Taulukko 8. Botaanisen analyysin tulokset v. 1948 perustetun kenttäkokeen sadosta v. 1950 (kylvetty $30 \mathrm{~kg} / \mathrm{ha}$, josta $64.2 \%$ Alopecurus pratensista, $12.4 \%$ Bromus inermistä, $6.2 \%$, Poa alpigenaa, $6.2 \%$ Poa trivialista ja loput muita nurmikasvilajeja).

Tabelle 8. Ergebnisse der botanischen Analyse in dem i.J. 1948 angelegten Feldversuch im Sommer 1950 (zur Aussaat gelangten $30 \mathrm{~kg} / \mathrm{ha}$ in folgender Verteilung: Alopecurus pratensis $64.2 \%$, Bromus inermis 12.4 $\%$, Poa alpigena $6.2 \%$, P. trivialis $6.2 \%$, der Rest andere Wiesenpflanzen).

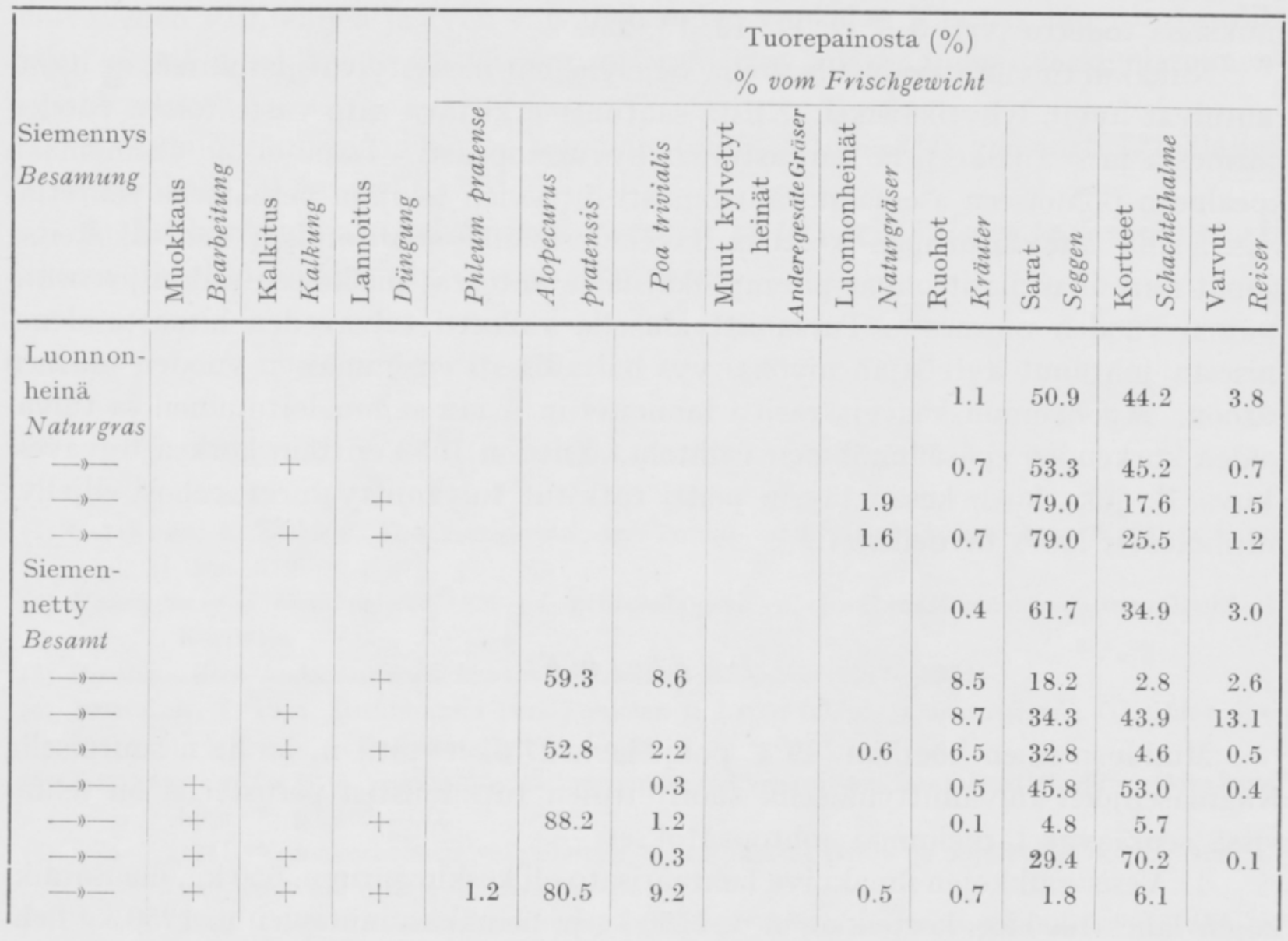

jen osuus sen mukaisesti, miten runsaasti kasvustossa oli kortetta ja heinäkasveja, vastaavasti joko suureni tai pieneni. Näyttää siis siltä, että Kaamasenjoen tulvavesi, joka kulkeutuu karuilta seuduilta, ei sisällä runsaasti ravinteita; siten sen merkitys tulvaniitylle rajoittunee pääasiassa vain kastelevaan, lämmittävään eli routaa sulattavaan sekä sammaltumista ehkäisevään vaikutukseen (vrt. 1 ja 12).

Viljeltyjen nurmikasvien kylväminen ei käytännöllisesti katsoen ollenkaan johtanut tulokseen, jos maata ei lannoitettu; lannoittamattomilla koealoilla viljelykasvit jäivät niin kituviksi, että niitä tuskin ollenkaan joutui korjattuun satoon. Lannoitetuillakin koealoilla useimmat kokeilluista nurmikasvilajeista kuten Trifolium pratense, T. hybridum, T. repens, Lotus corniculatus, Festuca pratensis, F. rubra, Dactylis glomerata, Agrostis stolonifera ja Bromus inermis menestyivät hyvin huonosti. Glyceria fluitans säilyi vetisillä alueilla kauan, mutta jäi hennoksi ja harvakasvuiseksi tuskin ollenkaan lisäten niityn satoa. Poa-lajit säilyivät niityllä sensijaan suhteellisen hyvin; Poa trivialisen osuus sadossa oli siemenmäärän pienuuteen nähden melko tuntuva (taul. 8). Viljellyistä nurmikasveista parhaiten menestyivät kuiten- 
kin Phleum pratense ja Alopecurus pratensis. Niiden sato, jos se lasketaan $15 \%$ vettä sisältäväksi (ilmakuivaksi), kohosi hehtaaria kohden suhteellisen ylävillä, lannoitetuilla niittyvyöhykkeillä 3000—4000 kg:n (taul. 5, 7; kuvat 4, 5, 8). Maan viettosuunnan mukaisesti sato kuitenkin nopeasti pieneni. Timotein sato aleni tällöin jonkin verran jyrkemmin kuin nurmipuntarpään. Eri nurmikasvilajien tulvankestävyyssuhteet osoittautuivat varsin samanlaisiksi kuin aikaisemmin on muissa tutkimuksissa todettu (vrt. 5, 7, 9, 11, 12, 13, 23).

Niilläkin tulvaniittyalueilla, joilla viljelyheinät menestyivät parhaiten, ne osoittautuivat hyvin lyhytikäisiksi. Niistä saatiin merkittävä sato vasta toisen vuoden nurmessa ja sen jälkeen ne surkastuivat hyvin nopeasti. Tämä ei ole yksinomaan koealueen pohjoiseen asemaan välittömästi liittyvien tekijäin perusteella selitettävissä, sillä Muddusniemen koetilan kivennäismailla suoritetuissa kenttäkokeissa samat nurmikasvilajit olivat pitempi-ikäisiä ja antoivat melkoisen sadon jo ensimmäisen vuoden nurmessa. Tulvaniittyalueella vaikutti tulvaveden hitaasta alenemisesta johtunut kylvöajan myöhäisyys haitallisesti ensimmäisen vuoden nurmen satoon. Myöhemmin kasveja rasitti lannoitetun maan sammaloituminen ja tulvaveden korkeuden epäsäännöllinen vaihtelu. Vuoden 1952 erittäin korkea tulvavesi (kuva 7), joka koko kesän täysin peitti tutkitut tulvaniittyalueet, tuhosi viljellyt nurmikasvit lähes täydellisesti.

\section{$P \ddot{a} \ddot{a} t e l m \ddot{a} t$}

Muddusniemen koetilan $\left(69^{\circ} 4^{\prime}\right.$ pohj. lev., $27^{\circ} 3^{\prime}$ it. pit.) n. 50 ha:n suuruisella Kaamasenjoen tulvaniittyalueella suoritettujen tutkimusten perusteella on tehtävissä seuraavat tärkeimmät johtopäätökset:

1. Vesisaraikkojen ilmakuiva hehtaarisato oli keskimäärin n. $650 \mathrm{~kg}$, maasaraikkojen lähes $1000 \mathrm{~kg}$, korteikkojen n. $1150 \mathrm{~kg}$ ja heinäkasviniittyjen n. $1250 \mathrm{~kg}$ hehtaaria kohden. Satojen vaihtelu eri vuosina ja niityn eri alueilla oli suuri (140$1720 \mathrm{~kg} / \mathrm{ha})$.

2. Saraikkojen ja heinäkasviniityn satojen pienuus johtui suureksi osaksi kasvualustan ravinneköyhyydestä, mutta myös tulvaveden korkeuden suurista vaihteluista.

3. Lannoituksella oli suuri vaikutus tulvaniityn sadon määrään. Kun tulvaniitty voi joinakin vuosina jäädä melkein kokonaan veden alle, tuntuu lannoituksen taloudellinen kannattavaisuus kuitenkin epävarmalta.

4. Lannoitus lisäsi erityisesti tulvanarkojen kasvilajien (heinäkasvit ym.) osuutta kasvustoissa. Siten se heikensi kasvustojen tulvankestävyyttä. Kun sitä paitsi lannoituksen vaikutus osoittautui hitaaksi, kohdannee tulvaniityn tarkoituksenmukainen lannoittaminen suuria vaikeuksia.

5. Kalkituksella, varsinkin lannoituksen ohella, oli pikemminkin haitallinen kuin satoa lisäävä vaikutus.

6. Tulvaniitylle kylvetyt 15 nurmikasvilajia eivät ilman lannoitusta antaneet satoa. Lannoitetulla tulvaniityllä niistä menestyivät parhaiten timotei- ja nurmi- 
puntarpää, mutta runsaan sadon ne antoivat vain heinäkasvi-maasaravyöhykkeellä. Silloinkin kun tulvaveden liiallinen korkeus ei ollut ehdottomana esteenä, varsinainen sato saatiin vain $1-2$ vuotena.

7. Kylvetyt heinälajit antoivat eräissä kokeissa satoa lannoitetun luonnorheinän sekaan kylvettyinä. Yleensä ne kuitenkin saivat jalansijaa vain muokatussa maassa, jossa niiden sato poikkeuksetta oli runsain (huippusato n. $4000 \mathrm{~kg} / \mathrm{ha}$ ). Tulvaveden vaihtelujen ja työn vaivalloisuuden vuoksi ei Kaamasenjoen tulvaniittyjen yleistä muokkausta voitane ennen huomattavia vedenpinnan laskemistoimenpiteitä toteuttaa.

8. Lannoitetun maan nopea sammaloituminen ilmeisesti vaikeutti heinälajien menestymistä tulvaniityllä.

9. Karhunsammal (Polytrichum swartzii) ja timotei (Phleum pratense) sietivät jokseenkin yhtä ankaran tulvavesivaikutuksen.

\section{KIRJALLISUUTTA}

(1) Cajander, A. K. 1909. Die Alluvionen der Tornio- und Kemi-Thäler. Acta Soc. Sci. Fenn. Tom. 37,5 .

(2) Handledning i försöksteknik 1939. Lantbrukshögskolan. Jordbruksförsöksanstalten. Medd. 1. Norrtälje.

(3) Ilmatieteellisen keskuslaitoksen kuukausikatsaukset sääoloihin 1947-1952.

(4) Jutila, K. T. 1926. Tutkimuksia Perä-Pohjolan ja Lapin talous- ja asutusoloista III. Maanviljelyksestä. Acta Forestalia Fennica 28.

(5) Kaitera, Pentri 1935. Viljelyskasvien kyvystä kestää vesipeittoa. Maataloustieteellinen Aikakauskirja 7 , p. $107-121$.

(6) —— 1941. Vedenkorkeuden vaihteluiden vaikutuksesta pelto- ja niittyviljelykseen. Maatal. hall. vesitekn. tutkim. 3. Helsinki.

(7) —— 1941. Maataloushallituksen vesiteknillisissä tutkimuksissa suoritetuista vesivahinkokokeista. Maanv.ins. yhd. vuosik. 1941, p. 5-28. Hämeenlinna.

(8) Parvela, A. A. 1934. Inarin viljelykasvisto ja pääpiirteitä sen historiasta. Acta Agralia Fennica 31. 3, p. $61-83$.

(9) Reyntens, H. 1949. Onderzoek betreffende de weerstand tegen overstroming van verschillende grasen Durmevaller. Mededelingen van de Landbouwhogeschool en de opzoekingsstatiions van de staat te Gent 14, p. 251-262.

(10) Risku, Анті 1939. Kemijärven vedenkorkeuksien vaikutuksesta tulva-alueen viljelykseen ja kasvistoon. Maanv.ins.yhd. vuosik. 1939, p. 176-190. Hämeenlinna.

(11) Roivainen, H. 1937. Nurmiviljelyksen mahdollisuuksista Perä-Pohjolassa ja Lapissa. Suomen laidunyhd. julk. 12, p. 7-25. Vammala.

(12) Saukko, Pentti 1946. Rantaniittyjen tuotosta. Maanv.ins.yhd. vuosik. 1946, p. 67-85.

(13) —- 1946. Saimaan rantapelloilla suoritettuja viljelykasvien vesivahinkotutkimuksia. Maataloushallituksen vesiteknillisiä julkaisuja 4 .

(14) —- 1947. Rantakasvustojen korjuusta. Maatalous 40, p. 37-40;49-51.

(15) Suomen tilastollinen vuosikirja, Helsinki.

(16) Teräsvuori, Kaarlo 1920. Muistiinpanoja Pohjois-Savon luonnonniityistä. Suom. Maataloustiet. Seur. Julk. 4.

(17) —— 1920. Niittyluokittelusta Suomen maataloudellisessa ja kasvimaantieteellisessä kirjallisuudessa. Acta Agralia Fennica 18.3, p. 59-66. 
(18) - 1926. Wiesenuntersuchungen I. Ann. Soc. Zool.-Bot. Fenn. Vanamo 5, n:o 1, p. 1-162.

(19) - 1927. Wiesenuntersuchungen II. Ibid. 7, n:o 3, p. 312-392.

(20) - -1928 . Niittyjen jyvittämisestä. Viides maatalousviikko, p. 109-119. Porvoo.

(21) - 1931. Eräitä niittyjen jyvityksessä huomioon otettavia seikkoja. Maanmittaus 1931. Ylipainos, p. $1-16$.

(22) - 1934. Niitty Suomen maataloudellisessa kirjallisuudessa. Acta Agralia Fennica 31.4, p. $85-101$.

(23) VÄRE, Matti 1947. Maan vesisuhteista ja viljelyskasvien sadoista Maasojan vesitaloudellisella koekentällä 1939-1944. Maa- ja vesiteknillisiä tutkimuksia 5. Helsinki.

\title{
REFERAT:
}

\section{UNTERSUCHUNGEN AN ÜBERSCHWEMMUNGSWIESEN AUF DEM VERSUCHSGUT DER UNIVERSITÄT HELSINKI IN MUDDUSNIEMI, INARI}

\author{
Aus dem Pflanzenpathologischen Institut der Universität Helsinki
}

Die Untersuchungen wurden in den Jahren 1947-1954 auf den Überschwemmungswiesen des Flusses Kaamasenjoki, 69 4' n.Br. und 27 $3^{\prime}$ ö.L., im nördlichen Lappland ausgeführt. Die Wasserstandsschwankungen waren erheblich (Abb. 2); i. J. 1952 lag die Wiese den ganzen Sommer unter Wasser (Abb. 7), Auch in anderen Jahren waren die Erträge schwach (Abb. 3, Tab. 1). Durch reichliche Volldüngung liess sich der Ertrag merkbar heben (Tab. 2), Kalkung dagegen blieb erfolglos (Tab. 4) trotz des sauren Bodens ( $\mathrm{pH} 4.3-5.0$ ). Die Düngung bewirkte eine Änderung der Vegetationszusammensetzung (Tab. 4). Gesäte Wiesenpflanzen gediehen nur in gedüngtem Boden und nur an den höchsten Punkten der Überschwemmungswiese (Abb. 4, 5; Tab. 4, 5, 6, 7, 8). Die Höhe des Wasserstandes schwankte jedoch von einem Jahr zum anderen dermassen, dass die landwirtschaftliche Nutzung der Flächen eine künstliche Wasserstandssenkung untedingt notwendig macht. 